\title{
APPLICATIONS OF ADVANCED PETROLEUM PRODUCTION TECHNOLOGY AND WATER ALTERNATING GAS INJECTION FOR ENHANCED OIL RECOVERY - MATTOON OIL FIELD, ILLINOIS
}

COOPERATIVE AGREEMENT NUMBER DE - FC22 - $93 B C 14955$

\author{
AMERICAN OIL RECOVERY, INC. \\ DECATUR, ILLINOIS
}

Date of Report:

Award Date:

Anticipated Completion Date:

Government Award Current Year:

Program Manager:

Principal Investigator:

Technical Project Officer:

Reporting Period:
December 21, 1993

December 29, 1992

December 31. 1994

Michael R. Baroni

Michael R. Baroni

Gene Pauling

THIRD QUARTER 1993

\section{DISCLAIMER}

This report was prepared as an account of work sponsored by an agency of the United States Government. Neither the United States Government nor any agency thereof, nor any of their employees, makes any warranty, express or implied, or assumes any legal liability or responsibility for the accuracy, completeness, or usefulness of any information, apparatus, product, or process disclosed, or represents that its use would not infringe privately owned rights. Reference herein to any specific commercial product, process, or service by trade name, trademark, manufacturer, or otherwise does not necessarily constitute or imply its endorsement, recommendation, or favoring by the United States Government or any agency thereof. The views and opinions of authors expressed herein do not necessarily state or reflect those of the United States Government or any agency thereof.

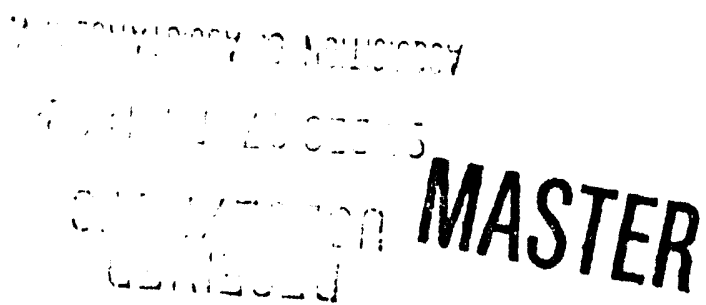




\section{OBJECTIVES}

The objectives of this project are to continue reservoir characterization of the Cypress Sandstone; to identify and map facies-defined waterflood units (FDWS); and to design and implement water-alternating-gas (WAG) oil recovery utilizing carbon dioxide $\left(\mathrm{CO}_{2}\right)$. The producibility problems are permeability variation and poor sweep efficiency. Part 1 of the project focuses on the development of computer-generated geological and reservoir simulation models that will be used to select sites for the demonstration and implementation of $\mathrm{CO}_{2}$ displacement programs in Part 2. Included in Part 1 is the site selection and drilling of an infill well, coring of the Cypress interval, and injectivity testing to gather information used to update the reservoir simulation model. Part 2 involves field implementation of WAG. Technology Transfer includes outreach activity such as seminars, workshops, and field trips.

\section{SUMMARY OF TECHNICAL PROGRESS}

\section{DRILLING, GEOPHYSICAL AND PETROHYSICAL ANALYSES OF SEAMAN No. 15}

A joint team of American Oil Recovery, Inc. project personnel and ISGS geoscientists selected Section 35, T12N R7E for location of the infill well, AOR/Seaman No. 15 based on the isopach of the target facies-defined subunit ("E"-interval) in the Sawyer Unit and information from surrounding wells (fig. 3). AOR/Seaman No. 15 was drilled from $9 / 12 / 93$ to $9 / 22 / 93$. The whole cores recovered from 1738' to $1822.5^{\prime}$ contained live oil in the "B", " $C$ " and " $E$ " intervals of Cypress Formation (fig.1). Core analyses showed that the " $E$ "-interval has a higher average porosity and permeability than the " $B$ "- and " $C$ "-intervals respectively (Table 1). A suite of geophysical logs comprising of dual induction focus log, natural gamma ray log, compensated densilog/caliper, compensated neutron log, minilog, dielectric log and analysis and epilog - complex reservoir analysis were run. The in-situ water saturation of the "E"-interval predicted from the logs were very high. For example, the $\mathrm{C}$-interval was calculated to have a water saturation of $100 \%$ by the dielectric log despite the fact that the whole core portion of Cinterval was observed to be oil saturated and bleeding oil and gas. Because of the uncertainty of the water saturations determined by use of "rule-of-thumb" values of exponent " $n$ " and the formation cementation factor " $\mathrm{m}$ " employed in the log interpretation, Cypress core samples from the B-, C- and E- intervals were submitted for an extended analysis of these critical factors.

\section{CYPRESS ROCKINJECTED BRINE COMPATIBILITY TESTS}

Two core plugs taken from the E-interval at depths of 1750.5 and 1751 feet respectively were tested for compatibility with (1) Cypress formation brine from Strohl No. 8, (2) produced brine from the Pennsylvanian formations, (3) pit brine consisting of Rosiclare and Cypress effluents, effluents from Pennsyvlanian formations and rain water, 
and (4) laboratory brine consisting of $1 \% \mathrm{NH} 4 \mathrm{Cl}$ and $1 \% \mathrm{NaCl}$. The resistivity and $\mathrm{pH}$ of the various test brines were measured at room temperatures ranging from $74.9^{\circ} \mathrm{F}$ to $77.3^{\circ} \mathrm{F}$ (Table 2). The fluids were injected into the plugs in the order shown in Table 3.

All field brines were first passed through the Whatman filter (No. 4) paper prior to injection into the core plug. The brines retained a yellowish taint after filtration. Liquid permeability was observed to decrease as the field brines were consecutively injected into the core plugs (Table 3). Also the color of the core effluents was clear suggesting that the plugs filtered out the yellowish taint. A dark-brown solid buildup was also observed on the inlet face of the core plugs. The liquid permeability increased from $14 \mathrm{md}$ to 19.3 md after the flow direction was reversed in plug No. 2 (Table 3), a sure indication that particle plugging occurred in the core sample. These observations suggest that these field brines may impair formation permeability if injected into the reservoir without adequate filtration.

SLIM-TUBE CO ${ }_{2}$-OIL MISCIBILITY TESTS TO DETERMINE MMP OF CYPRESS OIL $\mathrm{CO}_{2}$-crude oil miscibility tests were conducted in a slim-tube apparatus using Cypress crude oil sampled from the No. 8 Strong well (fig. 3). The test conditions were $85^{\circ} \mathrm{F}$ and pressure ranges of 1250 psig to 2500 psig. The slim-tube properties are summarized in Table 4 and the test results are summarized in Table 5. The plot of oil recovery at 1.2 PV of injected $\mathrm{CO}_{2}$ versus pressure is illustrated in Figure 2. The minimum miscibility pressure of the Mattoon crude oil with $\mathrm{CO}_{2}$ was determined to be 1780 psig using the method of Yellig and Metcalf (1978).

The above result implies that only immiscible $\mathrm{CO}_{2}$ displacement of oil is possible from the Cypress reservoirs at Mattoon field since the formation parting pressure is about 1,800 psia.

\section{RESERVOIR SIMULATION}

Reservoir simulation models of the Mattoon $\mathrm{CO}_{2}$ Project have been developed to enhance and verify reservoir characterization, and to predict optimum $\mathrm{CO}_{2}$-assisted oil recovery processes. The models, which are being continously updated, will aid in the design and management of Part 2 of this project. The three major models are: the Sawyer $\mathrm{CO}_{2}$ Injection, the Pinnell $\mathrm{CO}_{2}-W A G$, and the "huff ' $n$ ' puff" (cyclic $\mathrm{CO}_{2}$ injection using data from the AOR/Seaman No. 15 well) models.

\section{Sawyer Unit $\mathrm{CO}_{2}$ Project}

During the last quarter, approximately 2000 tons of $\mathrm{CO}_{2}$ were injected into No. 1 Sawyer Community and oil produced from No. 2 Ed. Morris and No. 1 D.M. Sawyer Community 2 (fig. 3). ICCR No. 18 and ICCR No. 19 wells were monitored and found to contain $\mathrm{CO}_{2}$. After the cessation of $\mathrm{CO}_{2}$ injection on June 30,1993, ICCR No. 18 and ICCR No. 19 wells and No. 1 Sawyer Community injection well were used to monitor reservoir pressure. There was a general pressure decrease in all these wells as oil production continued from No. 2 Ed. Morris and No. 1 D. M. Sawyer Community wells 
(fig. 4). Uniformity of pressure responses confirm communication among these wells in the E-interval.

Continuing and extensive search for well information in this unit revealed that twelve wells were completed for oil production from the "E"-interval at various times between June 1946 and February 1962. Furthermore, four wells including the Railroad No. 18 well, previously used as water injectors, were open in the "E"-interval. Only three wells - No. 1 Sawyer Community \#3, No. 1 Sawyer Community \#2 and Railroad No. 19 were opened in the "E"-interval during the current project. The implication of this finding is that the "E"-interval has been produced.

A compositional reservoir simulation model consisting of six pseudo-components (Table 6) was developed to assist in the management of the project in the Sawyer Unit. Reservoir description was initially accomplished by correlations of reservoir quality (clean sand distribution) to porosities and the permeability-porosity correlation of the Cypress sandstone. This data has been greatly improved by the core analysis of the AORSeaman No. 15 well in the Sawyer Unit. Pseudo-relative permeability data were replaced with laboratory-measured values using Cypress rock from the newly-drilled well, Cypress brine and $\mathrm{CO}_{2}$-saturated crude oil. History match was greatly improved. One drawback is that there is no gas data to date and simulated gas production could not be matched by observed data.

Planned predictions using the simulation model include the comparison of the performances of multiple well oil production and gas injection to those of the cyclic $\mathrm{CO}_{2}$ injection and oil production otherwise called 'huff and puff'. The uncertainty of the integrity of wells that are open in the "E"-interval and the high cost of verifying them favor 'huff and puff' operations in the Sawyer Unit.

\section{Single Well Cyclic $\mathrm{CO}_{2}$ Injection in Sawyer and Strong Units}

Parameters affecting oil recoveries from "huff and puff" wells have been investigated by simulation of a single well model. The core analysis and well data of the AOR-Seaman No. 15 well were used in the simulation (Table 7). The parameters included in the sensistivity analysis are: the $\mathrm{CO}_{2}$ slug size, the number of $\mathrm{CO}_{2}$ injection cycles, the $\mathrm{CO}_{2}$-oil mixing ratios, and permeability-thickness of the reservoir interval.

Simulated results show that the oil production rate increases after injecting $\mathrm{CO}_{2}$ into the single well (fig. 5). Other results are (1) oil recovery increases with $\mathrm{CO}_{2}$ slug size reaching a peak after $2 \%$ HCPV (7.64 MMSCF) is injected but declines between $2 \%$ HCPV and $3 \%$ HCPV; (2) increasing permeability values also increases oil recovery and also cumulative gas production at the same slug size (fig. 6); (3) a second cycle of $\mathrm{CO}_{2}$ injection may increase the oil flow rate at the same well conditions and (4) oil recovery increases with $\mathrm{CO}_{2}$ /crude oil mixing ratio (fig. 7). Other factors that increase the $\mathrm{CO}_{2}$ /crude oil mixing ratio include absence of thief zones in the reservoir, and initial reservoir pressure (fig. 2).

These results suggest that (1) there is a $\mathrm{CO}_{2}$ slug size for optimum oil production from a given "huff and puff" well; (2) oil production from a "huff and puff" well may be optimized by well stimulation that can increase the well productivity without creating fractures and channels; and (3) a second cycle of $\mathrm{CO}_{2}$ injection may enhance oil recovery

qtr3/.rpt/pps/12.21.93/ 
from the "huff and puff" well.

The next stage of the simulation of the "huff and puff" process involves matching the simulation model to observed results from actual "huff and puff" wells in order to develop a suitable model that can be used to advise future applications of "huff and puff" projects.

\section{Pinnell $\mathrm{CO}_{2}$ WAG Project}

The reservoir simulation study of the Pinnell $\mathrm{CO}_{2}$-WAG project was performed using a black-oil model. The model was calibrated by matching oil production and pressure history between April 201993 and Sept. 30 1993. Performance of various $\mathrm{CO}_{2}$ injection scenarios were investigated with Pinnell-Uphoff No. 1 and Pinnell No. 3-W wells as the oil producer and gas-water injector respectively. The options considered are:

(1) Base Case : Continuous production from Pinnell-Uphoff No. 1 without pressure maintenance after May 15.

(2) Straight $\mathrm{CO}_{2}$ injection: Continuous $\mathrm{CO}_{2}$ injection at a rate of 500 MCF per day.

(3) Straight water injection: Continuous water injection at a rate of 125 barrels per day.

(4) Water alternating $\mathrm{CO}_{2}$ injection at various brine-to- $\mathrm{CO}_{2}$ slug ratios.

The following conclusions can be drawn from the results of this model (Table 8):

(a) Oil production from WAG injection is higher than that obtained from straight $\mathrm{CO}_{2}$ flood or straight water flood.

(b) Higher oil recovery was obtained with a WAG ratio higher than 1 MCF of $\mathrm{CO} 2$ per barrel of brine.

(c) Oil recovery by immiscible $\mathrm{CO}_{2}$ displacment of oil is sensitive to the mixing ratio of $\mathrm{CO}_{2}$ with crude oil. Oil recovery from straight $\mathrm{CO}_{2}$ flood is poor when the mixing ratio is low $(<20 \%)$. 
TABLE 1: CORE ANALYSIS SUMMARY

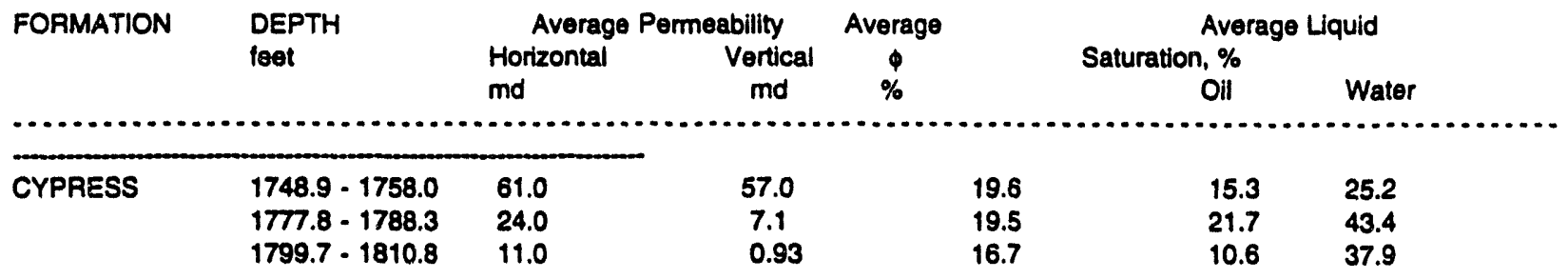

Table 2: CHEMISTRY OF BRINE USED IN THE ROCKBAINE COMPATIBILITY TESTS

\begin{tabular}{lllll} 
Type of Fluid & pH & Rw,ohm/m2 & TDS, ppm & Test Temp. F, \\
\hline Cypress brine & 6.97 & 0.074 & 37,768 & 74.9 \\
Pennsytvanian' & 7.54 & 0.113 & 20,804 & 77.3 \\
$\quad \begin{array}{l}\text { Pit brine } \\
\text { Lab. brine }\end{array}$ & 6.85 & 0.110 & 21,652 & 77.0 \\
Core effluent & 7.26 & 0.065 & 42,365 & 77.1 \\
from Cypress & & & & \\
brine & 7.36 & 0.076 & 35,400 & 76.3
\end{tabular}

Table 3: $\quad$ COREFLOW DATA IN THE ROCKBAINE COMPATIBILITY TESTS

\begin{tabular}{lcr} 
& Pluq 1 & Plug 2 \\
\hline Depth, tt & 1750.5 & 1751.0 \\
Air Permeability, md & 45.2 & 42.7 \\
Lab. brine perm., md & 13.5 & 14.04 \\
Cypress brine perm., md & - & 13.33 \\
Pennsylvanian' brine perm. md & 10.1 & 8.50 \\
Pit brine perm., md & 7.0 & 19.32 \\
Reverse flow - Cypress & &
\end{tabular}

1 Pennsylvanian brines consist of commingled produced brines from Pennsylvanian formations. 


\begin{tabular}{ll}
\hline Column material & 316 stainless steel \\
Length & 57 foet \\
Intemal diameter & $0.457 \mathrm{~cm}$ \\
Packing material & glass bead (100-120 mesh) \\
Porosity & $42.1 \%$ \\
Pore volume & $120 \mathrm{cc}$ \\
Pressure rating & $5000 \mathrm{psi}$ \\
Permeability & 4 darcies
\end{tabular}

Table 5:

OIL RECOVERIES AT VARIOUS SLIM TUBE PRESSURES

Pressure $\quad \%$ oll recovery
(psig)

\% PV CO2 injected

when gas oil

interface/transition

zone was observed

\begin{tabular}{lll}
\hline 1350 & 74.86 & $72 \%$ \\
1500 & 81.67 & $79 \%$ \\
2000 & 90.01 & $91 \%$ \\
2500 & 91.40 & $95 \%$
\end{tabular}

Table 6 - PROPERTIES AND COMPOSITIONS OF PSEUDO-COMPONENTS IN RESERVOIR CRUDE OIL

Reservoir Temperature $=80^{\circ} \mathrm{F}$

\begin{tabular}{|c|c|c|c|c|c|c|}
\hline $\begin{array}{l}\text { Pseudo- } \\
\text { component }\end{array}$ & $\begin{array}{l}\text { Composit } \\
\text { Mole trac }\end{array}$ & $\begin{array}{l}\text { ition } \\
\text { etion }\end{array}$ & ents & $\begin{array}{l}\text { Molecular } \\
\text { Weight } \\
\text { gm/gmmole }\end{array}$ & $\begin{array}{l}\text { Critical } \\
\text { temp. } \\
{ }^{\circ} \mathrm{F}\end{array}$ & $\begin{array}{l}\text { Critical } \\
\text { Pressure } \\
\text { psia }\end{array}$ \\
\hline $\begin{array}{l}\mathrm{CO}_{2} \\
\mathrm{P2} \\
\mathrm{P3} \\
\mathrm{P4} \\
\mathrm{P5} \\
\mathrm{P6}\end{array}$ & $\begin{array}{l}0.0004 \\
0.0036 \\
0.06253 \\
0.08171 \\
0.3522 \\
0.49955\end{array}$ & $\begin{array}{l}\mathrm{CO}_{2} \\
\mathrm{~N}_{2} \\
\mathrm{C} 1, \mathrm{C} 2, \mathrm{C3} \\
\mathrm{C} 4, \mathrm{C5} \\
\mathrm{C} 6, \mathrm{C} 7, \mathrm{C} 8, \mathrm{C9} \\
\mathrm{C} 10, \mathrm{C} 33\end{array}$ & $\begin{array}{l}44.01 \\
28.01 \\
36.11 \\
65.32 \\
103.11 \\
388.53\end{array}$ & $\begin{array}{c}87.9 \\
-232.4 \\
119.8 \\
342.84 \\
553.61 \\
1104.7\end{array}$ & & $\begin{array}{l}1070 \\
493 \\
639.16 \\
518.51 \\
435.76 \\
212.15\end{array}$ \\
\hline
\end{tabular}


Table 7 - RESERVOIR PROPERTIES USED IN SINGLE WELL SIMUIATION (AOR/SEAMAN NO. 15)

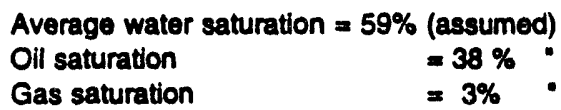

\begin{tabular}{|c|c|c|c|}
\hline \multicolumn{4}{|c|}{ Permeability, md } \\
\hline Depth, feet & Horizontal & Vertical & Porosity, \% \\
\hline 1750 & 71.0 & 54.0 & 20.9 \\
\hline $1750-1751$ & 73.0 & & 19.6 \\
\hline $1751-1752$ & 119.0 & & 20.2 \\
\hline $1752-1753$ & 73.0 & 67.0 & 20.7 \\
\hline $1753-1754$ & 60.0 & & 21.3 \\
\hline $1754-1755$ & 28.0 & & 19.5 \\
\hline $1755-1756$ & 54.0 & 49.0 & 21.0 \\
\hline $1756-1757$ & 11.0 & & 13.5 \\
\hline $1757-1758$ & 2.1 & & 13.8 \\
\hline
\end{tabular}

Table 8 - CUMULATIVE OIL PRODUCTION RATIO (RELATIVE TO BASE CASE) FROM APRIL 201993 TO DEC 301995

Mixing Ratio (\% of HCPV contacted by $\mathrm{CO}$ )

$5 \% \quad 20 \% \quad 50 \%$

$\begin{array}{llll}\text { CO2 flood } & 0.75 & 1.4 & 3.2 \\ \text { Brine flood } & 2.4 & 2.5 & 3.1 \\ \text { WAG }(1: 2)^{2} & 2.6 & 3.8 & 5.7 \\ \text { WAG }(1: 1) & 2.6 & 3.7 & 5.0 \\ \text { WAG }(2: 1) & 2.6 & 3.5 & 4.2 \\ \text { WAG (3:1) } & 2.6 & 3.2 & 3.8\end{array}$

(Ref: YELLUG. W.F. and METCALFE, R.S., Determination and prediction of CO2 minimum miscibility pressure :Paper SPE 7477. presented at the 53rd annual SPE technical conference and Exhibition. Houston, Texas October 1-3,1978)

${ }^{2}$ WAG (1:2) means water alternating gas ratio of 15,000 barrels of water to $30,000 \mathrm{MCF}$ of $\mathrm{CO}_{2}$ ) 
Core \# 11738-1760

Core 22', recover 20.35'

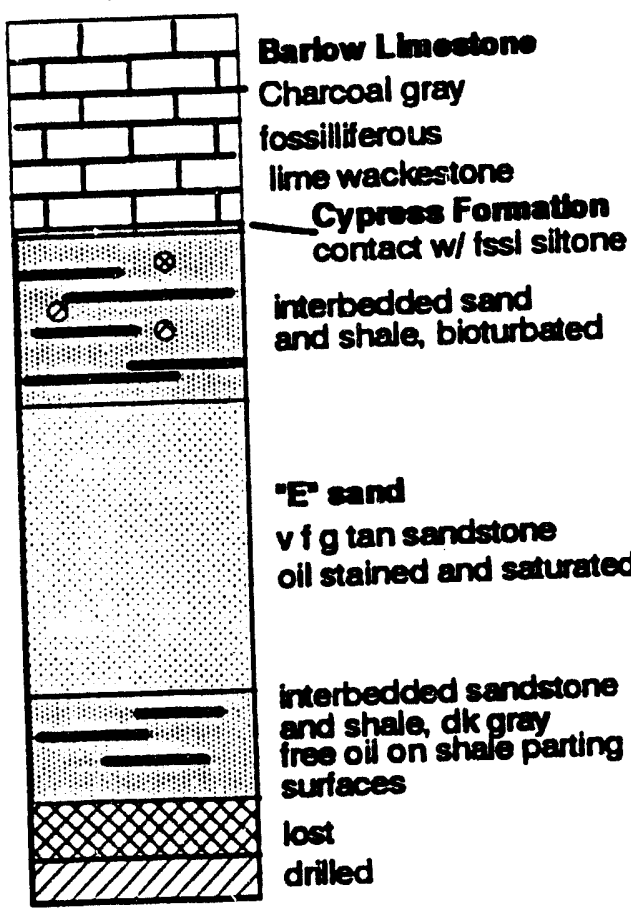

\section{American Oil Recovery Seaman \#15 Proliminary results of coring operations 9/16/92-9/18/92}

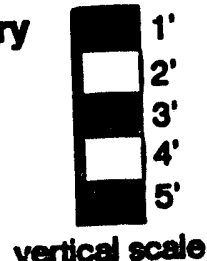

Core \# 2 1761-1791

Core 30', recover 30'

Core \# 3 1792-1822.5

Core 30.5', recover 28.9'

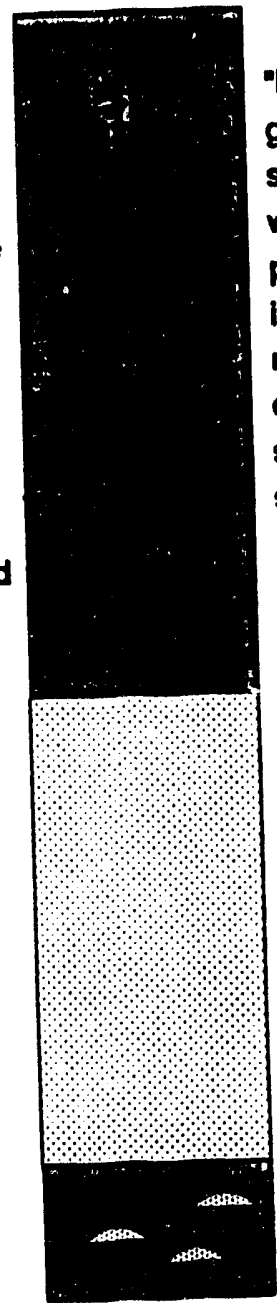

-D Intarval gray-green siltstone with some shale; plant fossils in top foot red precipitate on fracture surfaces, crumbly; slickensided surfeces

$C$ and vif g sandstone ton-light brown oil seturated bleeding oil and gas

gray siltstone with spotty oil stain in sand lenses

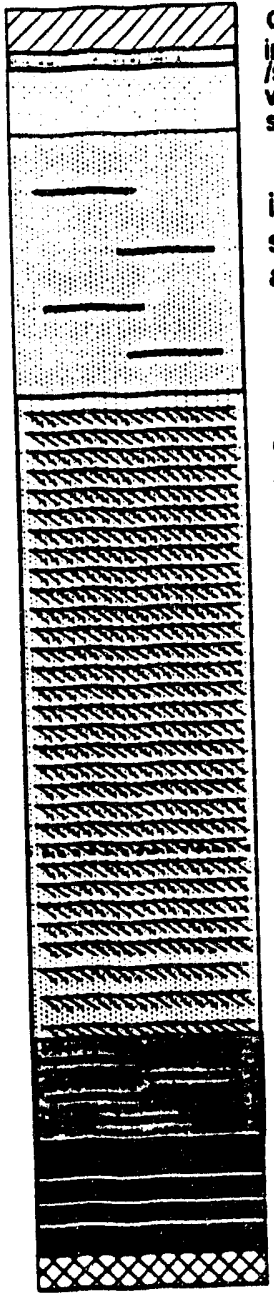

drilled

interbedded shale

sendistone saturated, bleeding oil \& ga

interbedded vf grained sandstone

and shale, no stain

"B" sand very fine grained cream colored sandstone, ripple bedded, upper 10.8 oil stained. few spots of bleeding oil \& gas lower

5.2' not stained

oil stain ends @ 1812.1'

vig sandstone with shale laminae Thinly laminated interbedded green shale and white sandstone, tempestites lost

Figure 1:

First-pass whole core description of Cypress interval from AOR/saeman No. 15 well 


\section{Slim tube tests}

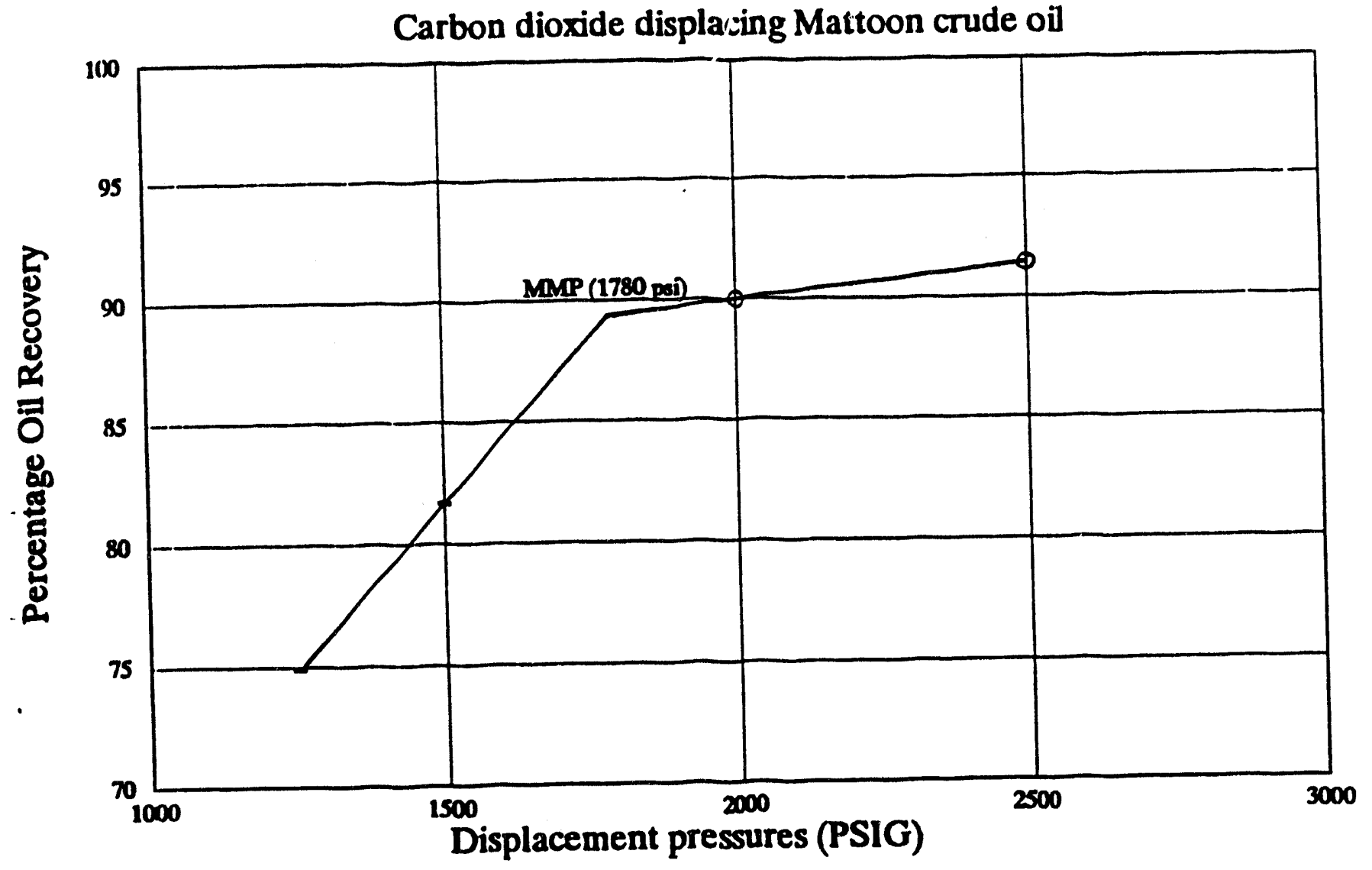

Figure 2:

Percentage oil recovery versus displacement pressure from slim tube tests. the minimum miscibility pressure is 1780 psi. Miscible displacement of oil with $\mathrm{CO}_{2}$ may only occur above this pressure. 
Figure 3:

Location map of the Mattoon CO2 Project area showing units. -

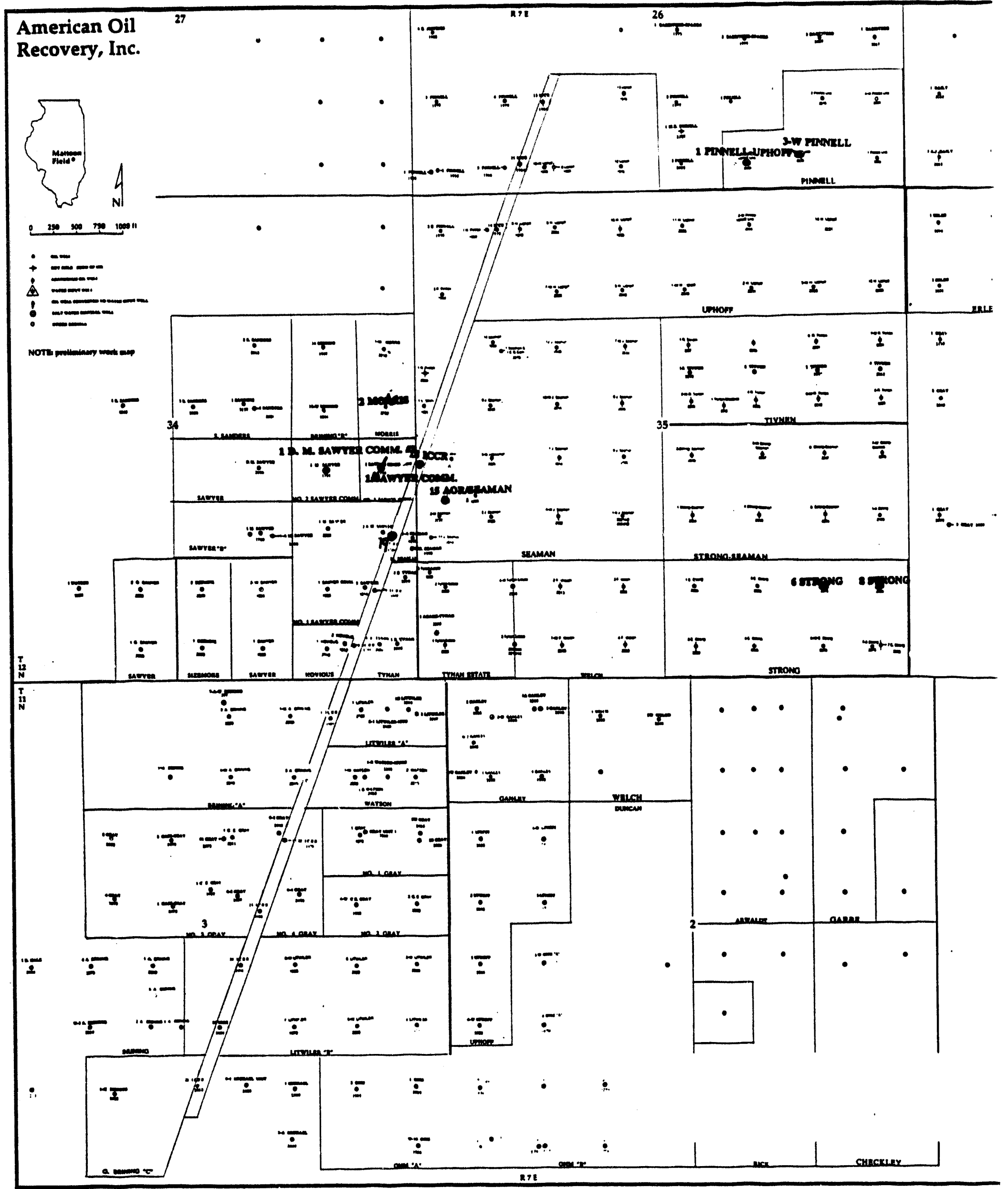




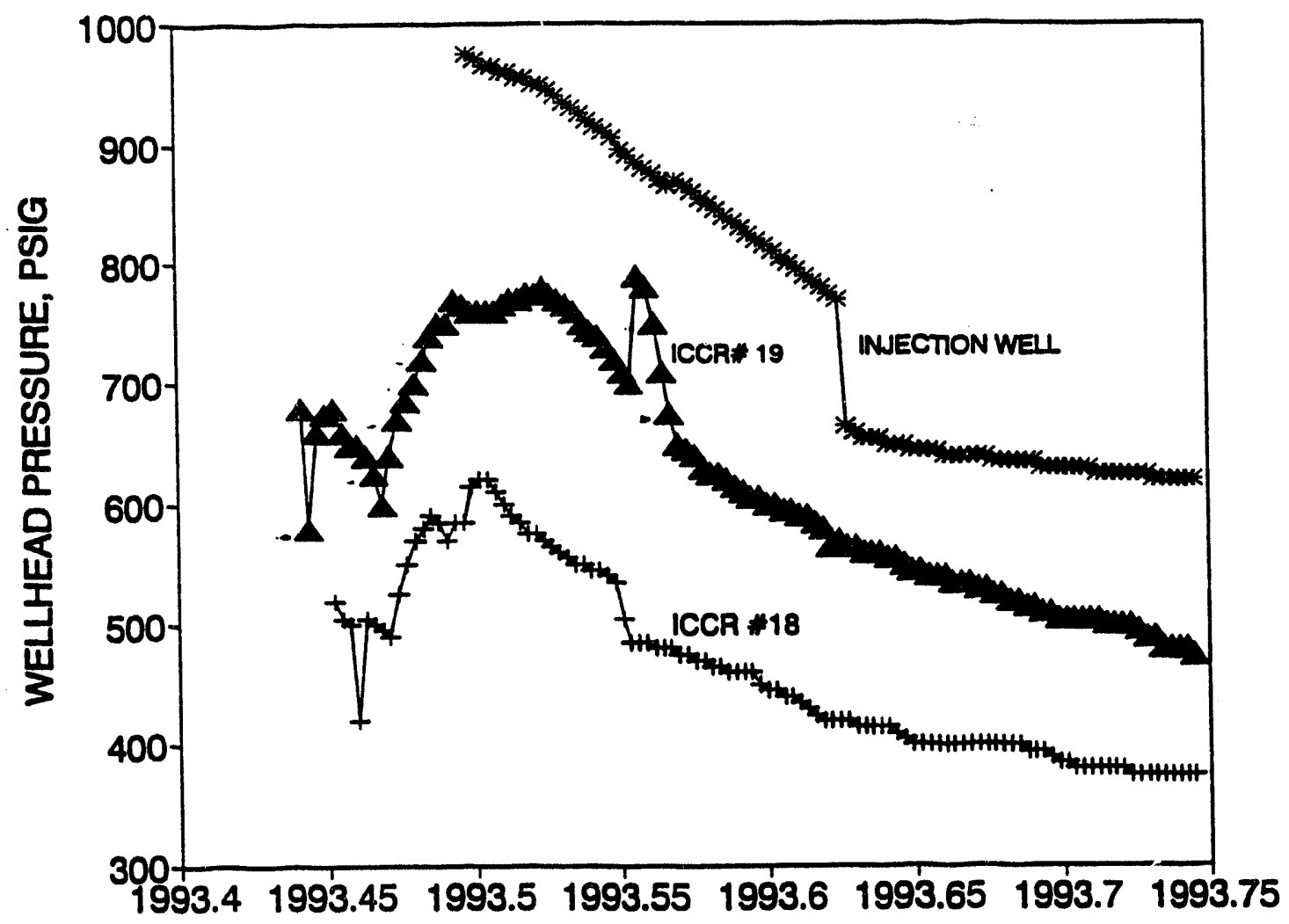

Figure 4:

Wellhead pressures of injection well (Sawyer 1 Community 3), ICRR \#18 and ICRR \#19. Identical pressure profiles indicate communication among the wells. 


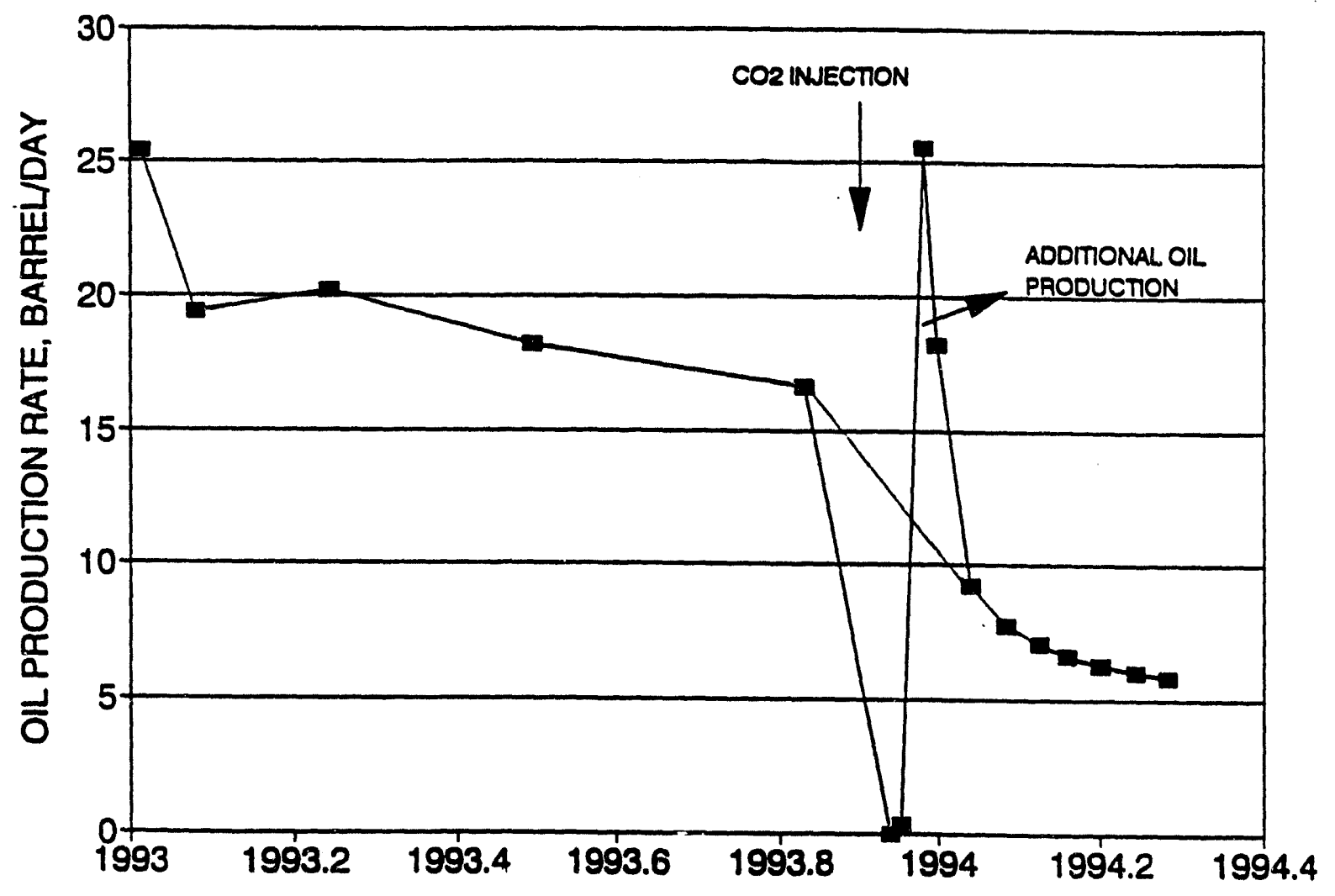

Figure 5:

Oil Production rate is increased by the $\mathrm{CO}_{2}$ cyclic injection processes. 3.82 MMSCF of $\mathrm{CO}_{2}$ was injected into 10 feet of pay. 


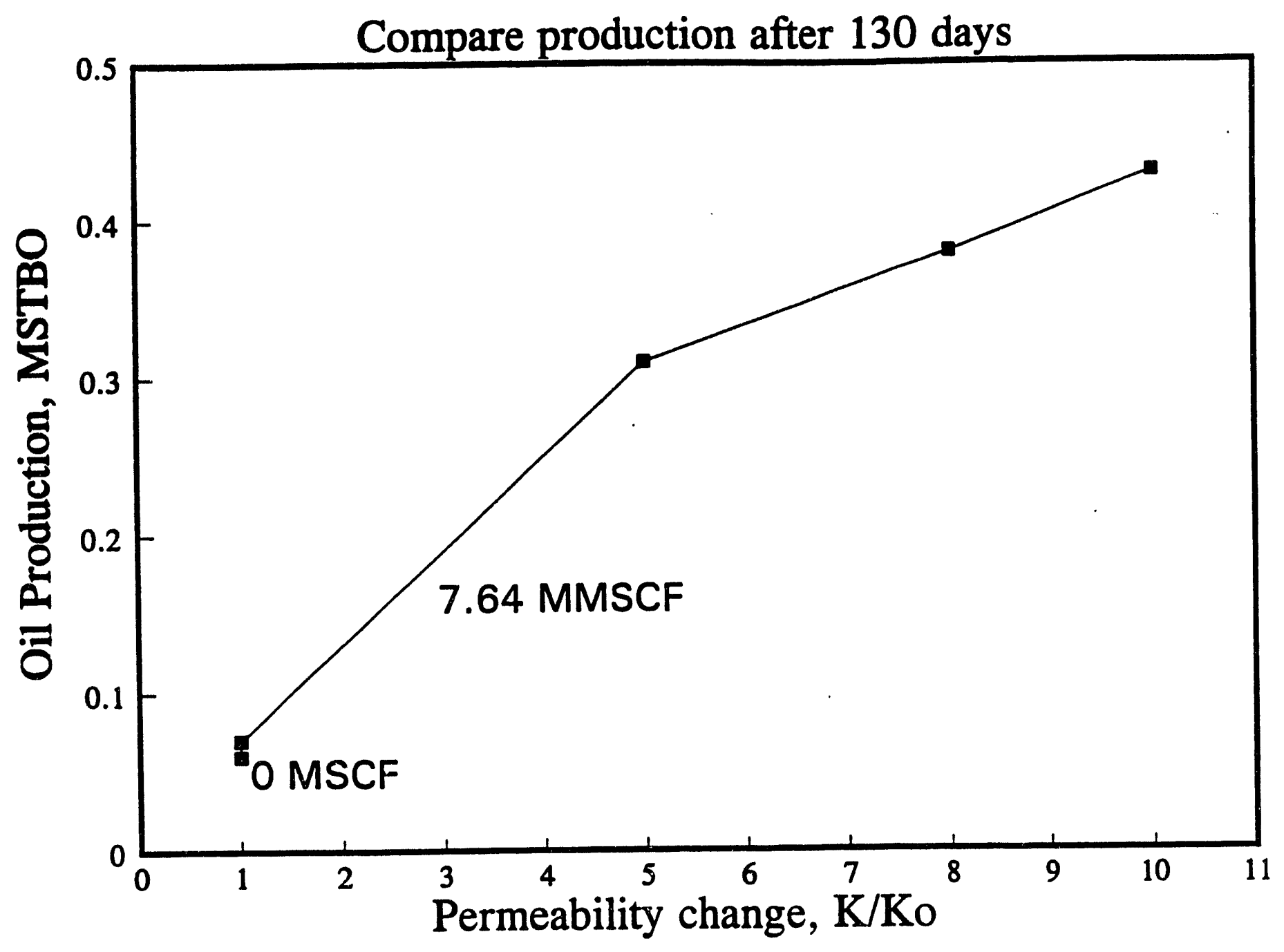

Figure 6:

Oil recovery is enhanced with improved reservoir permeability. 


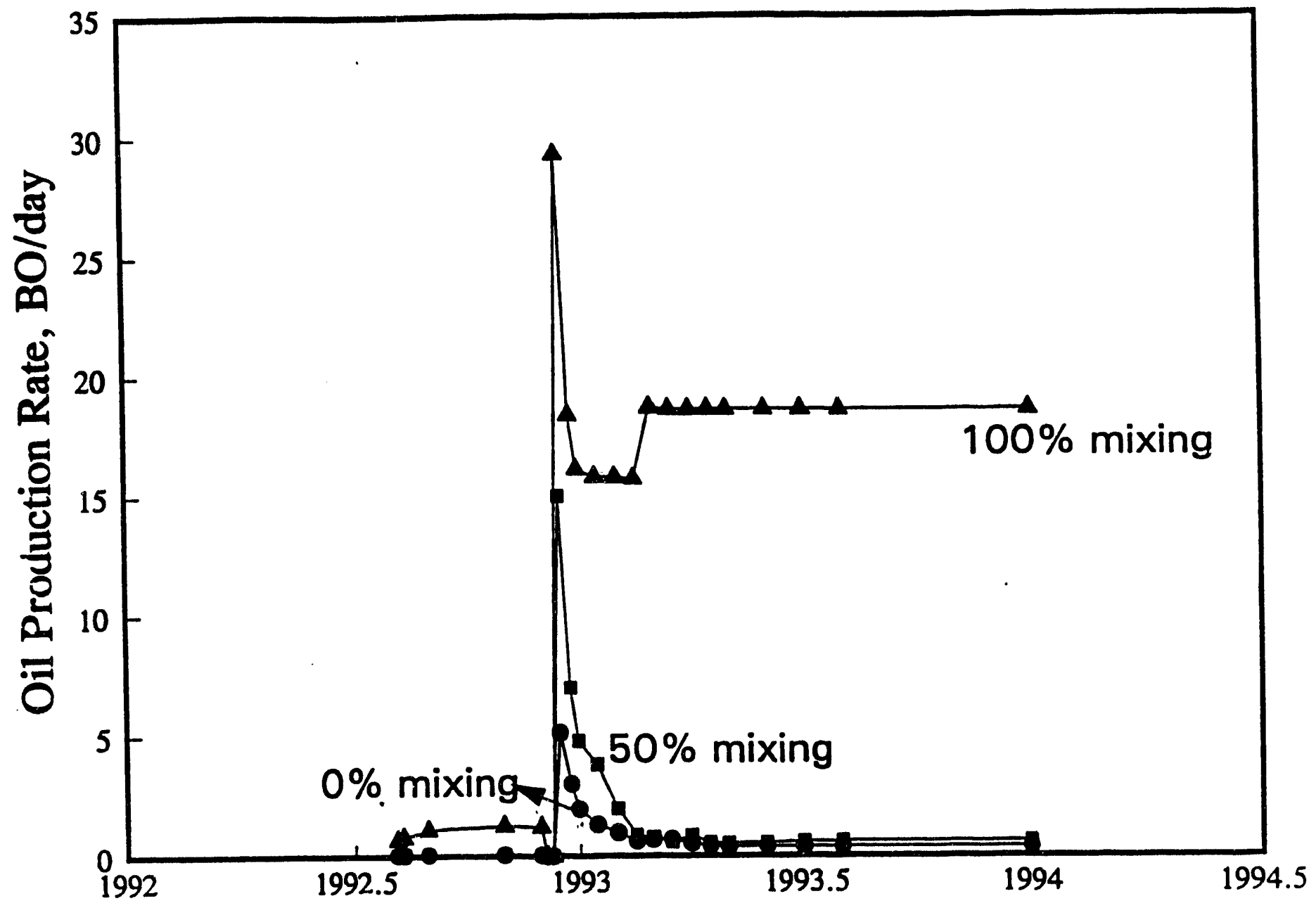

Figure 7: $\quad$ Oil recovery rate increases with increasing CO2-crude oil mixing ratio. 

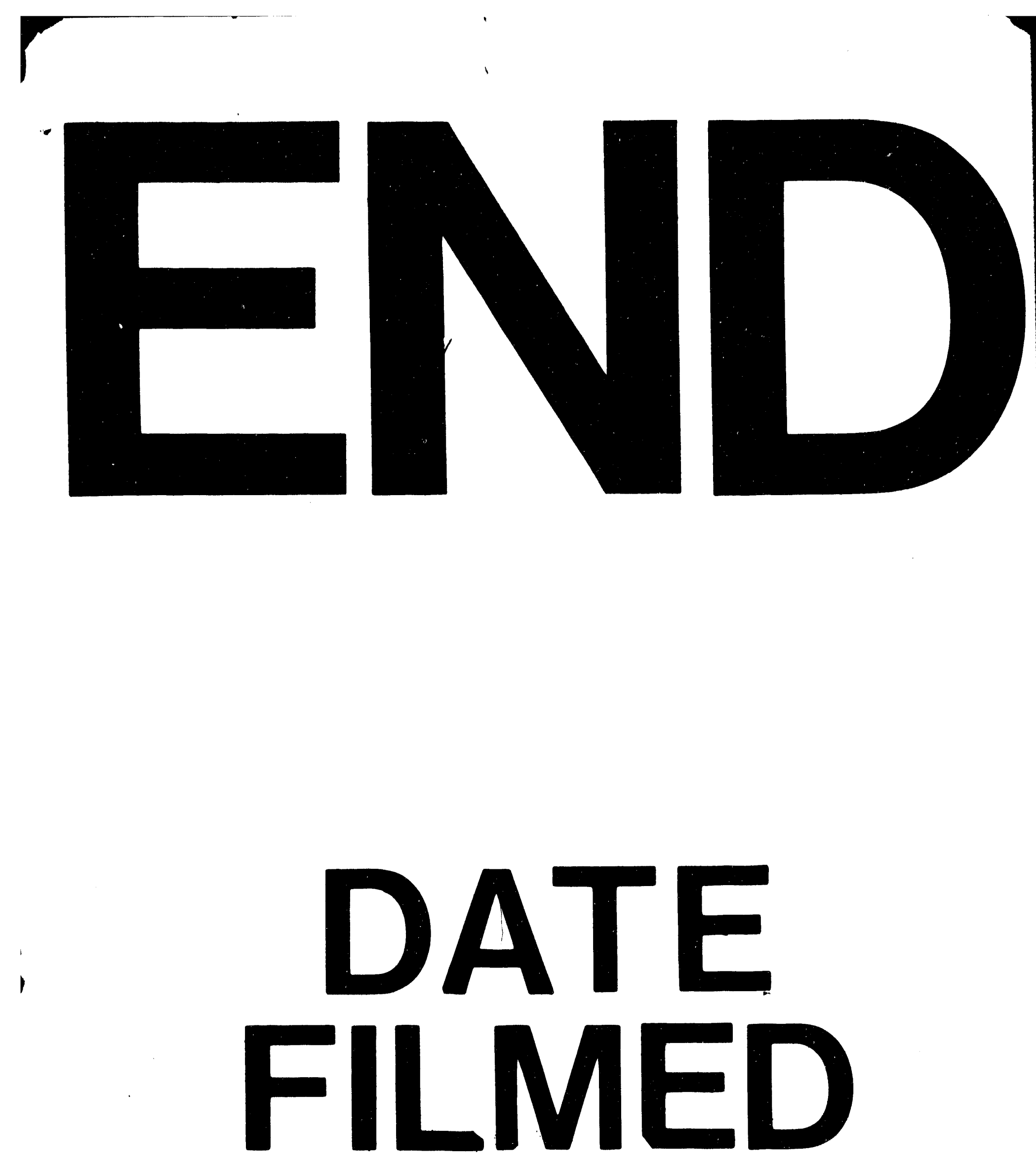

1

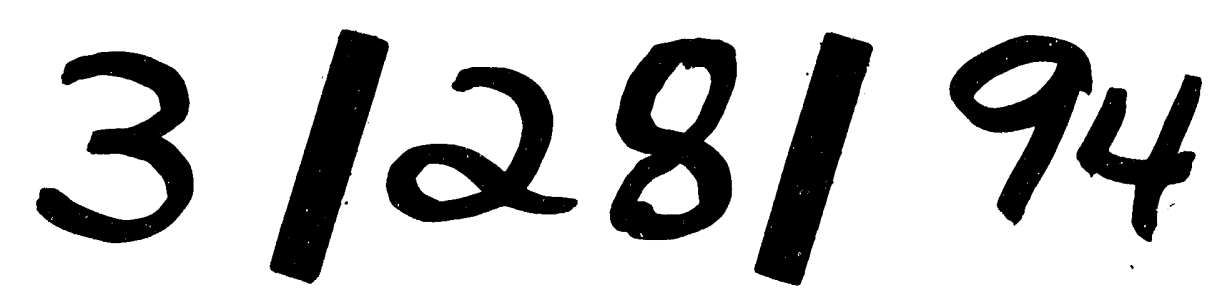




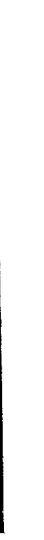

